\title{
The southern Rhine graben: A new view of the initial phase
}

Received: 28 June 2002 / Accepted: 19 September 2003 / Published online: 15 April 2004

(C) Springer-Verlag 2004

Abstract One of the puzzling features of the southern end of the Rhine graben is the Dinkelberg-Tabular Jura block on the eastern shoulder of the graben. It is dissected by a large number of faults, the most notable ones forming a field of narrow little grabens and half-grabens whose bordering faults converge at the level of the Middle Triassic evaporites, which points to décollement at that horizon. The little grabens were traditionally considered to be of Oligocene age, coeval with the main taphrogenesis of the Rhine graben. Two hypotheses were offered for their formation, one ascribing them to extension on the extrados of large basement folds, the other to gravity sliding on paleoslopes. Recent field work uncovered overwhelming evidence for an Eocene age of the little grabens, the time of the initial phase of Rhine graben formation. At that time there were neither large basement folds nor paleoslopes of any significance, and therefore the two hypotheses offered until now do not work. However, the map-view pattern of the field of faults offers a somewhat unusual way out of the dilemma. This pattern is most prominently displayed in the Dinkelberg area north of the Rhine. There a lane of narrow décollement grabens with a mean NNE strike is confined within the NW- striking Dinkelberg graben, which is much wider and rooted in the basement. It is also very shallow, with a subsidence on the order of $100 \mathrm{~m}$. The lane of décollement grabens forms a dextral en-échelon pattern with respect to the Dinkelberg graben, suggesting stretching of the post-evaporite sequence above a basement essentially extended by strike slip. This model, though not as clearly expressed, is also compatible with the data in the rest of the DinkelbergTabular Jura block. It also fits surprisingly well a theoretical model by Withjack and Scheiner (1982) that pre-

\section{H. Laubscher $(\square)$}

Geol.-Paläontolog. Inst.,

Universität Basel,

Bernoullistr. 32, 4056 Basel, Switzerland

e-mail: hans.laubscher@unibas.ch

Tel.: +41-61-2673613

Fax: +41-61-2673519 dicts a dominance of strike-slip in the marginal area of a system consisting of extension superimposed on doming.

Keywords: Grabens · Doming · Décollement · Faulting · Horizontal Shear $\cdot$ Mechanical Stratigraphy

\section{Introduction}

The Rhine graben is the most prominent member of the essentially Paleogene Western European Rift system (Fig. 1, inset) (Ziegler 1990). This article focusses on its southern end, where in the west a diffuse transfer zone connects it with the Saone-Rhone grabens, whereas in the east the Dinkelberg-Tafeljura (=DT) block forms an in-

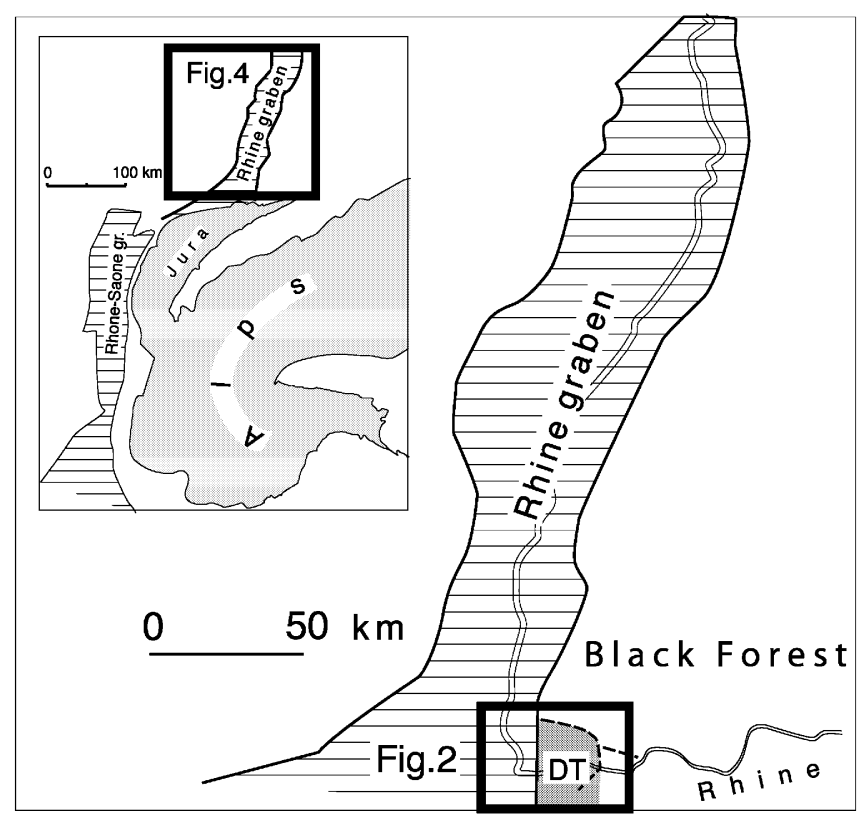

Fig. 1 Location of the Dinkelberg-Tabular Jura block (DT, shaded) at the SE corner of the Rhine graben. Inset: The Rhine-Rhone graben system in the context of the Alps-Jura part of the AfricaEuropa plate boundary zone 


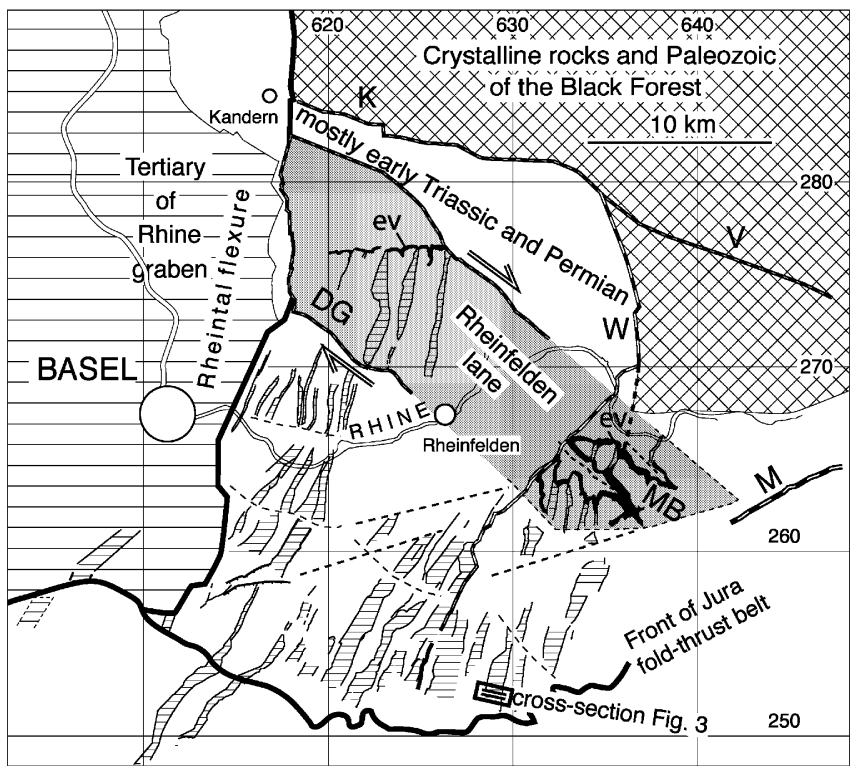

Fig. 2 The Rheinfelden lane in DT. The lane consists of the "Central Dinkelberg graben" $(D G)$ in the NW and the Mumpf-Buus domain $(M B)$ in the SE, separated by the Rhine valley where outcrops are rare. Black: Middle Triassic evaporites $(e v)$; narrow horizontal ruling: shallow grabens containing Late Triassic to Early Tertiarysedimentary rocks, forming the DT graben fieled; faults with late Paleozoic forerunners: $K=$ Kandern fault, $W=$ WehratalZeiningen fault zone, $\mathrm{V}=$ Vorwald fault, $M=$ Mandach line (margin of late Paleozoic graben zone, reactivated particularly in the Tertiary). Dashed lines are lineaments suggesting potential basementrooted strike-slip zones. Coordinates are those of the Swiss cartography

termediate step between the Rhine graben and the Black Forest. Although the DT block has been the object of research for more than a hundred years, many problems still have not been solved yet. This applies particularly to the problem of dating the several phases active from its initial formation in the Eocene to its subsequent modifications (e.g. Laubscher 2001). It is the initial, Eocene phase, that is the subject of this article.

More than a hundred years ago, geologists, particularly those of the Rhine graben universities of Basel, Freiburg and Strasbourg began to map the area at the southern end of the Rhine graben, to describe what they saw, and also to form concepts regarding its origin (e.g. Buxtorf 1901, Cloos 1910, Blösch 1910). With respect to the puzzling southeastern corner, it was Bubnoff (1912) who not only described the Dinkelberg block which characterizes it, but also offered ideas regarding the mechanics of its formation. To the south, across the Rhine, the Dinkelberg block continues into the Tabular Jura (Tafeljura) with a similar structure but a more complete stratigraphic record. One of the more enigmatic aspects of the DT block, already recognized by Bubnoff, is the incontrovertible observational fact that some of the faults that subdivide it are basementrooted, although a field of narrow grabens, which is also characteristic, does not penetrate below the Middle Triassic evaporites (Fig. 2). Apparently, then, these grabens developed above a décollement horizon in the evaporites.
In the past, essentially two hypotheses have been offered to explain both graben formation and décollement. The first (e.g. Bubnoff 1912) postulated regional basement folds coupled with stretching of the extrados. Bubnoff accepted the décollement hypothesis of Buxtorf (1907) for the neighboring Jura fold-thrust belt and voiced the opinion that both décollement processes might be due to a push from the Alps, the DT block forming above basement folds produced by this push. The second hypothesis advocated gravity sliding on paleoslopes as no sufficiently pronounced basement folds could be found (Laubscher 1982). Both hypotheses focussed to a great deal on the problem of the age of the grabens in relation to the contemporaneous regional frame. In addition, a debate raged at the time as to the mechanical causes for the graben field, apart from décollement (e.g. Bubnoff 1921). That was a time when geologists generally relied mostly on intuition as consideration of the physics involved became popular only decades later. As a consequence the ideas that were offered then have all been abandoned in the meantime.

\section{The Eocene age of the DT graben field}

The crucial age problem has been and still is only gradually being clarified, partly because the field evidence is scattered in an area that lacks conspicuous outcrops. The first thorough work on the graben structures was performed by Buxtorf (1901). He found that the grabens are pre-early Miocene as they are unconformably covered by a thin veneer of the early Miocene Upper Marine Molasse. He concluded that their age was Oligocene, the same age as the neighboring Rhine graben was considered to be at that time.

In the area where Buxtorf worked, the graben content consists solely of Mesozoic beds, all the younger beds having been removed by the pre-early Miocene erosion. Subsequently, field work done farther south, where younger beds survived the erosion, cast doubts on Buxtorf's conclusions. It was particularly Senn (1928), who found evidence that at least the first motions in an important member of the graben family had taken place in the Eocene. This, however, was not accepted by Buxtorf (1928), whose authority prevailed. Much later Hauber (1960) found other indications for Senn's view, without, however, taking sides in the dispute.

Whereas all of this field work covered only small areas, it was Laubscher (e.g. 1995, 1998) who embarked on a regional re-mapping campaign. He found compelling evidence for an Eocene age of all the members of the graben family that contained Eocene beds. This evidence consists of the insertion of beds of coarse conglomerates and breccias in the Eocene sequence on the one hand, and the absence of such a sequence, except for meager relics, outside the grabens on the other hand. 
Multiple hypotheses of the origin of the DT graben field in an Eocene regional frame

This new dating, it turns out, is a critical constraint for the hypotheses of graben formation. As to the hypothesis of large basement folds, there is regional evidence that no such folds sufficient for the stretching involved in the graben formation existed in the Eocene (compare, e.g., Schumacher 2002, for the Rhine graben, Laubscher 2001, 2003 for its southeastern end). The basement high of the neighboring Black Forest is much younger (e.g. Diebold 1990, Diebold et al 1991, Luterbacher et al. 1992, Laubscher 2001). The same argument applies to gravity sliding on paleoslopes. In particular, the slopes advocated by Laubscher (1982), i.e. the flexures in the WehratalZeiningen fault zone and the Rheintal flexure at the southeastern corner of the Rhine graben, are essentially due to an early Miocene phase of compression (for a recent reassessment see Laubscher 2001, 2003). Earlier structures would not have provided any mentionable slopes.

Verification of regional décollement at the base of the DT graben field

Consequently, both hypotheses - extrados stretching and paleoslope gliding - are ruled out. What else, however, could have initiated the formation of the DT graben field? At first sight it appeared that the two hypotheses exhausted the dynamical possibilities. Both of them are based on the assumption, supported by field evidence, that there was regional décollement of the graben field on the Middle Triassic evaporites. This evidence is found to be extremely robust. In the Dinkelberg block, where the Middle Triassic and its substrate are exposed at the surface, the graben field is still found to be restricted to the post-Lower Triassic strata (Fig. 2). In the southern part of the DT, where the sedimentary section is more complete but the base of the grabens is not exposed, arguments can only be based on the construction of cross-sections, as data from seismic lines (Gürler et al. 1987 were permitted to inspect proprietary seismic data; another seismic survey (Sprecher \& Müller 1986) farther east does not touch the DT area) are poor and inconclusive.

The geometry of the bounding faults is of crucial importance. There are only scattered exposures where elements of this geometry have been observed (e.g. Bubnoff worked in quarries in his time but they are now abandoned and overgrown; Brändlin 1912, Disler 1914, Buxtorf 1916, Heusser 1926, Meyer 2001), although mapping the faults has been comparatively easy because of the distinct stratigraphy. The faults are normal with dips mostly between 50 and 60 degrees. Traditionally, most cross-sections were constructed for the shallow part only, and no balancing was attempted. More recent work began to explore the deeper parts (Gürler et al 1987). Straight extrapolation of the bounding faults results in their convergence a little below the Triassic (Laubscher 1995). For this reason décollement on a postulated Paleozoic horizon was taken into consideration. However, graben extension demands that the bordering faults have moved apart in the course of graben formation, and therefore straight extrapolation of the present bordering faults results in an intersection below the actual décollement horizon.

\section{A balanced section across a DT graben}

In order to clarify this problem of fault intersection modified by décollement, forward modeling by means of a balanced cross-section is required. As the DT grabens and particularly their internal structure are not cylindrical, cross-sections cannot be perfectly balanced. Moreover, strike-slip components of movement and rotations in the grabens are probably present (see below and Richard et al. 1995) and introduce further errors. Still, the margins of error are arguably minimized by balancing.

I have analyzed somewhat extensively an example I found particularly well-exposed and instructive (Fig. 3). Fig. $3 \mathrm{a}$ is an attempt to assess the amount of stretching in the graben, using a well-exposed key bed. By retrodeformation $270 \mathrm{~m}$ of stretching are established. Straight extrapolation of the bordering faults combined with this amount of stretching defines a décollement in the Middle Triassic anhydrites (Fig. 3b). This conclusion is even more stringent if the rotations revealed by the key bed (Fig. 3a) are taken into consideration. These rotations indicate listric faults (Fig. 3c, d). In order to produce a kinematically viable balanced section, a simplified forward modeling procedure was chosen. The initial situation is shown in Fig 3b. It assumes that before the beginning of the actual motions two complementary straight normal faults were nucleated at one point on the décollement horizon. Moreover, the future graben content (horizontally ruled) was subdivided into two initial blocks, the shape of the eastern one taken from the length of the eastern key bed segment in Fig. 3a. This construction establishes quantities for both area and bed length conservation in step 2 (Fig. 3c) of the model. For this step it is assumed that the listric shape of the border faults is the result of modification of the initial faults by drag on the décollement horizon during subsequent extension by $270 \mathrm{~m}$ (compare the experiments by Horsfield 1980, McClay 1989). Step 2 is area-balanced, and in the neighborhood of the key bed it is bedlength-balanced, as well. In the deeper parts in which drag and rotation become severe, only area balancing was applied by trial and error. The severe deformations may have been accommodated by the Triassic evaporites. Evidently the observational evidence for this construction is incomplete, but several modifications have resulted in only minor differences, and I submit that the section not only is compatible with the present evidence but is robust as well with respect to further data that may be discovered in the future.

The particular example of Fig. 3 demonstrates that, when extension and listric shape of the graben faults are taken into consideration, the grabens depicted in the 
Fig. 3 a-d Balancing of a cross-section through a typical DT graben (for location see Fig. 2). a Establishing the amount of extension in a key bed from surface outcrops. b Pre-extension areas in a putative wedge-shaped embryonic graben. c The transfer by bedding plane slip of elements of (b) into listric fault boundaries (trial-and-error, area conservation, bedlength conservation in the shallow parts). d Stratigraphic elements involved in (c). Eocene redbeds are found in some parts but are eroded outside the graben
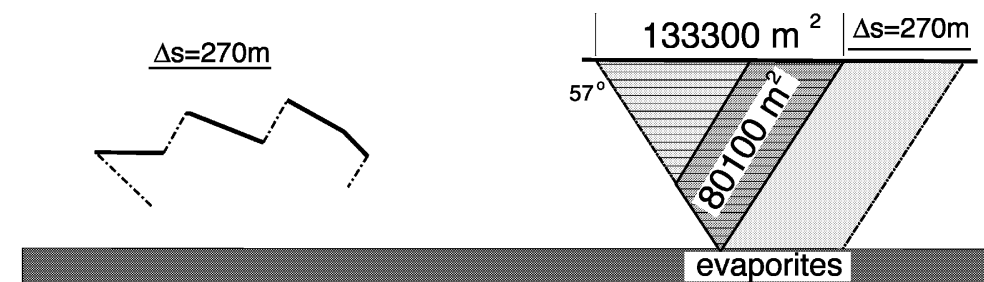

a

b

$1 \mathrm{~km}$

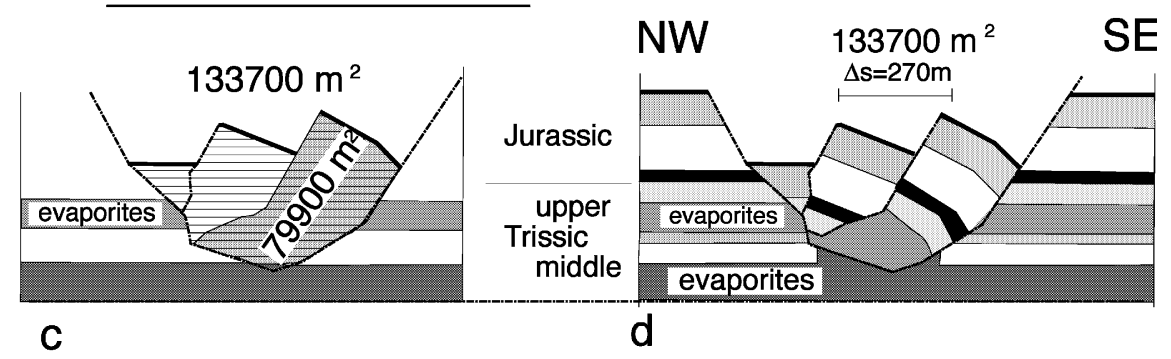

cross-sections of Laubscher (1995) all reveal décollement in the Middle Triassic rather than in the Paleozoic. Therefore, I consider the conclusion of the early researchers, and particularly of Bubnoff, confirmed, that there is décollement of the graben field on the Middle Triassic evaporites.

A new hypothesis of the formation of the DT graben field based on its relationship to deeply rooted faults

Returning to the question of how this décollement may have come about when both stretching on basement folds and sliding on paleoslopes are ruled out, let us consider the map-view pattern of the graben field (Fig. 2). It reveals a possible way out of the conundrum.

First note that although the narrow grabens do not extend below the Middle Triassic, there are faults in the DT area that do. What is the relationship between the two families of faults? There is one subarea where this relationship appears particularly clear, and this is the Central Dinkelberg graben (DG) of Bubnoff (1912). This graben is about $8 \mathrm{~km}$ wide and strikes NW, at about 60 degrees to the narrow grabens. It must be rooted deeply in the basement as its width precludes convergence of the bounding faults at a shallow horizon. That this is so may also be observed directly in some places. For instance, the southwestern border fault ("Rheinfelden fault"), is exposed except for a small interval that unfortunately contains the fault plane itself at the Rhine river at Rheinfelden, where it was observed and depicted as early as 1821 by Merian (compare Disler 1914) and in the former quarries near Degerfelden (Bubnoff 1912) at the road connecting the two towns of Lörrach and Rheinfelden (compare the map by Isler et al 1984). In these exposures the fault affects Lower Triassic and Permian. Moreover, subsidence in the DG is minimal (about 100-200 m) considering its width, and stretching - whatever the geometry of the faults chosen for extrapolation- is bound to be minimal as well. There may even be a component of compression. This is suggested by the examples of drag at the bordering faults observed by Bubnoff (1912) in some of the quarries exploited at the time, by the drag at the Rheinfelden fault exposed at Rheinfelden (e.g. Merian 1821, Disler 1914) and by flexures defining small folds as described by Heusser (1926) from exposures along the Rhine river.

This is the first conclusion about the relationship of the two families of faults: They apparently played entirely different kinematic and dynamic roles - décollement on the Middle Triassic evaporites and considerable stretching with the formation of shallow grabens on the one hand, basement-rooted faults with minimal stretching on the other hand.

However, this is not all. There is a peculiar array of narrow grabens within the confines of the Central Dinkelberg graben (DG, Fig. 2). It appears therefore that the two types of structure, although of entirely different kinematical roles, are intimately related. The array is one of dextral en échelon features associated with the DG. The conclusion seems inevitable: Apparently, there was a component of deep dextral shear (minimal throw in DG) associated with shallow stretching.

Does this relation also hold for that part of DT south of the Rhine? Inasmuch as no beds older than Middle Triassic are exposed except in a restricted area southeast of Rheinfelden (MB for Mumpf-Buus in Fig. 2), this question cannot be answered with certainty. In the MB area, which is in the direct prolongation of the Rheinfelden lane, although separated from it by the alluvial plain of the Rhine, the relationship clearly still holds. The difference is that no NW strking faults have been mapped in this area. However, there too are lanes of narrow grabens bottomed by the Middle Triassic evaporites, although they are bounded laterally by NW striking valleys rather 
than mapped faults. There may be faults in these valleys, but they would be of minimal vertical displacement. Similar remarks apply tho the rest of DT. In the Basel Tabular Jura SW of the Rheinfelden lane, NW-striking valleys are an important element of the geomorphology, although there is no obvious reason for their existence except the possibility of hidden fault zones which facilitated erosion. Again, these conjectured faults would be of minimal vertical displacement. However, the easily mapped narrow grabens appear to be discontinuous across them. In summary, the relationship of the deep and shallow families of faults or their possible representatives seems to hold equally for, or is compatible with, the rest of the DT block, although it is not as clearly demonstrable. Conservatively formulated, there is no evidence against a regional prevalence of the relations documented on the Dinkelberg.

A regional frame for the DT block and a model to account for its peculiarites

If the two hypotheses of shallow stretching on large basement folds and gravity sliding on paleoslopes are ruled out for the DT graben field, does the mechanics suggested by the DG hold any hope for a viable model? Next to the fact that there may be no alternative, the question arises whether the Eocene structural frame of the southern end of the Rhine graben is compatible with, or, even better, favorable for this mechanism.

The very early stages of the southern Rhine graben in the Eocene to early Oligocene were characterized by a concentration of faulting and subsidence in the partial graben of Dannemarie bordering the southern Vosges (e.g. Doebl 1970, Schumacher 2002). These were being uplifted at the time the graben subsided, albeit rather gently. Laubscher (1970), in an attempt to visualize the overall geometry of the Rhine graben and its surroundings, proposed early on a gentle domal uplift superimposed on the southern part of the graben. Among other things, this scenario would account for its widening "like a trumpet" (Cloos 1939) as it would be associated with essentially hyperbolical trajectories of principal stress. The situation, however, is not symmetrical on the side of the Black Forest east of the Rhine graben. There, it is modified by the presence of the Dinkelberg block, a modification most likely due to pre-existing Paleozoic faults (Diebold 1990, Diebold et al 1991, Laubscher 1986, 2001, 2003).

A perfectly symmetrical general model of extension superimposed on doming was presented by Withjack and Scheiner (1982), based on both analog modeling and analytical calculation (thin shell theory). The gist of the model which represents the initial, static phase of the structure is shown in Fig. 4. It predicts the dominance of strike-slip in the marginal area at the southern end of the graben. This is exactly the paleotectonic location of the DT block with respect to the Rhine graben. Therefore, the hypothesis suggested by the map-view pattern of the DT

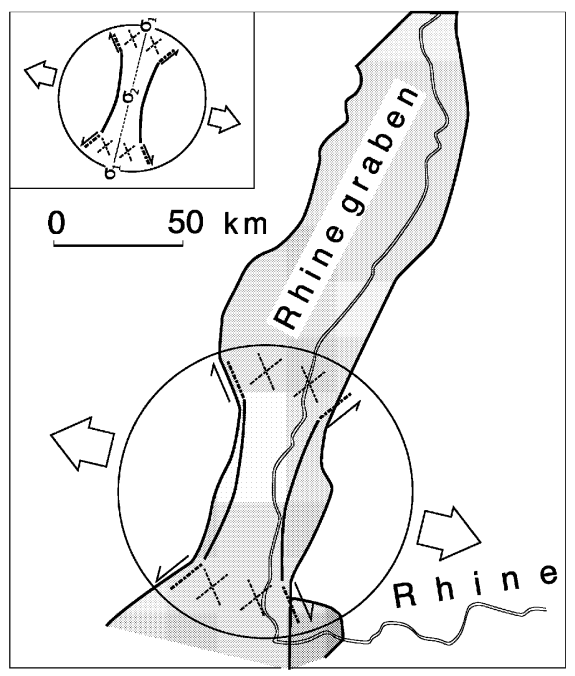

Fig. 4 The main features of the Withjack-Scheiner (1982) model: Horizontal extension superimposed on circular doming (inset) and its application to the southern Rhine graben. Heavy lines: Normal faults, dashed lines: Failure by horizontal shear. Notice that the principal stress trajectory shown in the symmetry axis switches the index.: It is $\sigma_{2}$ in the central part but $\sigma_{1}$ in the periphery

field of faults, unusual as it seems, is supported by both the regional frame in the Eocene and independent modeling.

\section{The $3 D$ problem}

Extension by normal faulting in a covering layer separated by a décollement horizon from a substrate deformed by horizontal shear is a 3D problem in an inhomogeneous medium that was not addressed by Withjack an Scheiner. On the other hand, there is observational evidence that these modes of deformation may alternate within a rock body, depending on changes in lithology (Lorenz et al 2002).

\section{A discussion of experimental work}

There is, moreover, a considerable body of experimental work that may have a an influence on the 3D situation of the DT block. In particular, this situation may be viewed as a modification and extension of the well-known analog models for the formation of en échelon structures in a deformable medium covering stiff boards that are displaced by strike-slip motion (e.g. Richard et al 1995). Instead of only one cut in the base board may be several parallel cuts applied and the strike-slip motion is performed on all of them (two cuts in Richard et al 1995, Fig 7). This approaches distributed simple shear in the substrate. Moreover, if the basement faults are inclined (normal), an obliquely extensional component may be introduced in the basement shear as illustrated by Richard et al (1995, Fig 11), a situation that seems particularly appropriate for the problem at hand. In the cover a field of 
deformation appears whose characteristics depend on its thickness and mechanical properties. Part of these characteristics are the angular relations between the strike of the basement fault and the various cover structures. With respect to this particular relation it will be mentioned that the experiments of Richard et al invariably produce smaller angles than those oberved in the DT block. How serious is this discrepancy, and what caveats have to be kept in mind when the real situation in nature is compared with the results of experiments?

I conjecture that the discrepancy is due to a number of important differences between the situation in nature and the experimental setup which reduce the applicability of the experiments. The most important physical conditions in nature that are not portrayed by the experiments seem to be: (1) Extreme decoupling between basement and cover at the evaporites which in the presence of water may be of vanishing strength; (2) Pronounced brittleness of the Mesozoic carbonates; (3) Comparative shearing strength and tensile weakness of these carbonates (a steep envelope of the Mohr circles) favoring breaks perpendicular to the regional $\sigma 3$; (4) The presence of inherited fault zones that convey an important anisotropy to the pre-Mesozoic rocks; the faults strike obliquely to the shear zones expected in a homogeneous medium; (5) The constraints imposed on the stress field are regional, as in a general and simplified way suggested by the Withjack \& Scheiner model, whereas in the experiments they are local, imposed particularly by the motion of the pre-sawed boards. Clearly, in a real, lithologically complex rock body, the separation of the various modes of failure will not be as simple as those predicted on the basis of experiments. In view of all these caveats, the relatively simple separation of the modes of deformation in the DT block is rather surprising.

A very interesting body of experiments pertinent to the problems discussed in this article are those recently performed by Callot et al. (2002). They model crustal-scale extension, but the problem of a stretched brittle cover (upper crust vs. Mesozoic carbonates) and a very weak, viscous substratum (ductile lower crust and ductile upper mantle vs. Triassic evaporites) is in some ways similar.

Joints and slickensides on reactivated joints

A microtectonic survey of the DT block was carried out some years after Bubnoff's mapping by Müllerried (1921). Although his report is not particularly inspiring, several inferences are possible. The faults are normal, and the striations on them are close to their dip. The much more numerous slickensides on reactivated near-vertical joints are preponderantly horizontal. As to the sense of shear, in the case of Müllerried's survey unfortunately no distinction was made between the roughness due to calcite steps or related extensional break-off phenomena and steps due to compressional oblique stylolites or "slickolites". Consequently, a mistaken sense of shear was often inferred. Thus, Müllerried assigned alternatively sinistral and dextral senses of motion to NE trending reactivated joints, whereas according to my own observations the sense of shear on these joints is invariably sinistral, and the complementary NW striking set exhibits dextral slickensides. However, I have not compiled a systematic record of these measurements. What can be inferred from these data? They are approximately compatible with widely distributed horizontal shear due to NS contraction and EW extension. Which of the several phases of deformation in the Alpine foreland may have produced them? While subduction to the SE and attendant compression was the dominant dynamical factor in the Neogene (Laubscher 2001, 2003; Schumacher 2002), regional WNW extension was the driving force in most of the EoOligocene. Although it is not possible at the present to decide which of the various Tertiary systems of motion contributed which component to the striations, they are compatible with the regional WNW extension in the Rhine graben.

\section{Conclusions}

The new-Eocene age assignment to the DT field of faults has done away with formerly offered explanations for the décollement of the field of narrow grabens. As neither large-scale basement folds nor gravity sliding on paleoslopes is even remotely suggested for that time by the data, there remains but the hypothesis of cover stretching by normal faulting above a substrate stretched at least partly by strike-slip motions (method of multiple working hypotheses). Although this unexpected solution may be arrived at by enumeration and elimination, it is first and foremost suggested by direct observation, particularly in the Dinkelberg area. Moreover, it is predicted in principle by analog modeling and anlytical calculation of horizontal extension superimposed on doming. These geometrically simple models fit surprisingly well the much more complex structural situation of the southern Rhine graben in the Eocene. Therefore, strange as it may seem at first glance, this hypothesis appears unavoidable.There is even an application of the new model to the southwestern end of the Rhine graben, where in the transfer zone of distributed sinistral shear (Basel-Dijon transfer zone) Rhine graben extension is transferred to the Saone (or Bresse) graben (Laubscher 1970): This corner is contained within the margin of distributed sinistral shear of the model (Fig. 4).

\section{References}

Blösch E (1910) Zur Tektonik des schweizerischen Tafeljura. Neues Jahrbuch für Mineralogie etc Beil Bd 29:593-680

Brändlin E (1912) Über tektonische Erscheinungen in den Baugruben des Kraftwerkes Wyhlen-Augst am Oberrhein. Mitt Grossh Bad Geol Landesanst 6:735-743

Bubnoff S von (1912) Die Tektonik der Dinkelberge bei Basel. Mitt Grossh Bad Geol Landesanst 6, 2:523-634 
Bubnoff S von (1921) Über Keilgräben im Tafeljura. Jber Mitt Oberrhein Geol Ver, NF 9:70-73

Buxtorf A (1901) Geologie der Umgebung von Gelterkinden. Beitr geol Karte Schweiz (NF) 11

Buxtorf A (1907) Zur Tektonik des Kettenjura. Ber Versamml oberrh geol Ver, 30./40. Versamml 1906/7:29-38

Buxtorf A (1916): Prognosen und Befunde beim Hauensteinbasisund Grenchenbergtunnel und die Bedeutung der letzteren für die Geologie des Juragebirges. Verh natf Ges Basel 27: 184254

Buxtorf A (1928) Über das oligocaene Alter der Verwerfungen im Schweizer Tafeljura. Eclogae geol Helv 21:337-338

Callot JP, Geoffroy L, Brun JP (2002): Development of volcanic passive margins: Three-dimensional laboratory models. Tectonics 21: 6 (DOI 10.1029/2001TC90101019)

Cloos H (1910) Tafel- und Kettenland im Basler Jura und ihre tektonischen Beziehungen nebst Beiträgen zur Kenntnis des Tertiärs. N Jb Mineral Geol Paläont Beilbd 30:97-232

Cloos H (1939) Hebung-Spaltung-Vulkanismus. Geol. Rundschau 30:401-527

Diebold P (1990) Die tektonische Entwicklung der Nordschweiz. Nagra informiert 2/90:47-54

Diebold P, Naef H, Ammann M (1991) Zur Tektonik der zentralen Nordschweiz: Interpretation aufgrund regionaler Seismik, Oberflächengeologie und Tiefbohrungen. NAGRA Tech Ber: NTB 90-04

Disler K (1914) Stratigraphie und Tektonik des Rotliegenden und der Trias beiderseits des Rheines zwischen Rheinfelden und Augst. Verh Naturf Ges Basel 25:1-96

Doebl F (1970) Die tertiären und quartären Sedimente des südlichen Rheingrabens. In: International Upper Mantle Project, Scientific Report 27:55-66

Gürler B, Hauber L, Schwander M (1987): Die Geologie der Umgebung von Basel. Beitr Geol Karte der Schweiz, N.F. 160, Bern

Hauber L (1960): Geologie des Tafel- und Faltenjura zwischen Reigolswil und Eptingen (Kt. Baselland). Beitr Geol Karte Schweiz, NF 112

Heusser H (1926): Beiträge zur Geologie des Rheintals zwischen Waldshut und Basel (mit besonderer Berücksichtigung der Rheinrinne) Dissertation, Universität Basel

Horsfield WT (1980) Contemporaneous movement along crossing conjugate normal faults. Jour Struct Geology 2:305-310

Isler A, Pasquier F, Huber M (1984) Geologische Karte der zentralen Nordschweiz 1:100 000, mit angrenzenden Gebieten von Baden-Württemberg. Nagra and Schweiz Geol Kommission, Spezialkarte Nr. 131

Laubscher H (1970) Grundsätzliches zur Tektonik des Rheingrabens. In: Illies JH, Müller St (eds) Graben Problems. Schweizerbart, Stuttgart: 79-86

Laubscher H (1982) Die Südostecke des Rheintalgrabens- ein kinematisches und dynamisches Problem. Eclogae geol Helv $75,1: 101-116$.
Laubscher H (1986) The eastern Jura: Relations between thinskinned and basement tectonics, local and regional. Geol Rundschau 73, 3:535-553

Laubscher H (1995) Neues zur Grenzzone Tafeljura-Faltenjura (Gebiet von Ziefen-Reigoldswil, Baselbieter Jura). Eclogae geol Helv 88:219-234

Laubscher H (1998) Der Ostrand des Laufenbeckens und der Knoten von Grellingen: Die verwickelte Begegnung von Rheingraben und Jura. Eclogae geol Helv 91:275-291

Laubscher H (2001) Plate interactions at the southern end of the Rhine graben. Tectonophysics 343:1-19

Laubscher H (2003) The Miocene dislocations in the northern foreland of the Alps: Oblique subduction and its consequences (Basel area, Switzerland-Germany). Jber Mitt Oberrhein Geol Ver, NF 85:423-439

Lorenz JC, Sterling JL, Schlechter DS, Whigham CL, Jensen JL (2002) Natural fractures in the Spraberry Formation, Midland basin, Texas: The effects of mechanical stratigraphy on fracture variability and reservoir behavior. AAPG Bull 86, 3:505-524

Luterbacher H, Köhler J, Winder H (1992) The northern margin of the Molasse Basin in SW Germany. Eclogae geol Helv 85, 3:787-788

McClay KR (1989) Physical models of structural styles during extension. In: Tankard AJ, Balkwill HR (eds) Extensional tectonics and stratigraphy of the North Atlantic margins. AAPG Memoir 46:95-110

Merian P (1821) Beiträge zur Geognosie, Bd 1. Übersicht der Beschaffenheit der Gebirgsbildungen in den Umgebungen von Basel. Basel, Schweighausersche Buchhandlung, 156 pp

Meyer M (2001) Die Geologie des Adlertunnels: Bull. angew. Geol. 6:199-208.

Müllerried F (1921) Klüfte, Harnische und Tektonik der Dinkelberge und des Basler Tafeljuras. Verh Naturhist-mediz Ver Heidelberg 15:1-46

Richard PD, Naylor MA, Koopman A (1995) Experimental models of strike-slip tectonics. Petroleum Geoscience 1:71-80.

Schumacher M (2002) Upper Rhine Graben: Role of preexisting structures during rift evolution. Tectonics 21: 6-1 - 6-17

Senn A (1928) Über die Huppererde von Lausen und das geologische Alter der Zeininger Bruchzone. Eclogae geol Helv 21:163-180

Sprecher C, Müller WH (1986) Geophysikalisches Untersuchungsprogramm Nordschweiz: Reflexionsseismik 82. Nagra Tech Ber $84-15$

Withjack MO, Scheiner C (1982) Fault patterns associated with domes- an experimental and analytical study. Bull. Amer. Assoc. Petroleum Geol. 66, 302-316.

Ziegler PA (1990) Geological Atlas of western and central Europe, 2nd Edition. Shell Internationale Petroleum Mij B V, and Geological Society London 